\title{
Natural capital accounting in the context of the socio-economic paradigm of financial reporting: conceptual and methodological aspects ${ }^{* * *}$
}

\author{
Irina Golochalova ${ }^{1}$, Oksana Vakun ${ }^{2}$ \\ ${ }^{1}$ Doctor of Economic Sciences, \\ Moldova State University \\ ${ }^{2} \mathrm{PhD}$, assistant professor, \\ West Ukrainian National University
}

JEL Classification: M41, Q57

\begin{abstract}
In the context of ensuring sustainable development, the activities of a business entity have come to be viewed as a threecomponent system designed to provide reliable information on the contribution of business to the social and environmental segments of the economy. This trend has led to the transition to the financial reporting socio-economic paradigm, which predetermines its revolutionary transformations, one of which is finding ways to recognize natural capital and disclose information about its impact on the business entity's value. In the article the conceptual foundation for the recognition of natural capital and impact of its disclosure in financial statements on the business entity's value has been provided. The methodological aspects of the recognition of two forms of natural capital (natural resources and ecosystem services) have been analyzed. The generalized model for the recognition of natural capital based on the IFRS system has been proposed. The system of accounting and financial reporting of the Republic of Moldova in the context of the transition to the socio-economic concept of disclosing information about the business entity's value has been characterized.
\end{abstract}

Keywords: natural capital; natural resource; financial reporting; socio-economic paradigm of financial reporting; IFRS methodology; recognition; assessment; accounting model.

\section{Introduction}

Impressive scientific and technological advances often lead to such an effect as the degradation and depreciation of natural capital, contrary to the expectations of economic development from their implementation, which, in fact, depends not only on the quality of the internal organization of a separate economic system or a separate business but also on the nature of the

Corresponding author:

${ }^{1}$ E-mail addresses: monomah5@yandex.ru

ORCID ID: 0000-0002-7552-6555

2 E-mail addresses: vakyn.o@gmail.com

ORCID ID: 0000-0002-7774-7204

(C) 2020 I.Golochalova, O.Vakun

doi: https://doi.org/10.26642/ppa-2020-2(2)-24-33 
interconnections of this system with the external environment. The reason for this phenomenon is the priority for the business environment of its capitalist values, which, according to researchers, is due to the following:

- the desire for endless accumulation of financial capital, which is carried out in two ways - the expansion of production through expansion and conquest of nature and the refusal to «pay the bills» [3];

- the lack of consistency between the economic activity of a single system and the possibilities of the environment in which it functions [13];

- $\quad$ the maximum benefit from all resources, able to improve the future conditions of its existence [18].

In the beginning, as a response to business ignorance of the social aspect of governance, the 1992 UN Conference adopted the Rio Declaration on Environment and Development, proclaiming the principle of caring for people, which are central to efforts to achieve sustainable development: the right to development must be realized in order to ensure equitable satisfaction for present and future generations in development areas and the environment [30]. Then the World Commission on Environment and Development developed a corresponding concept (1995), which indicates the indicators of sustainable development of social, economic and ecological subsystems [15]. The natural interaction of these three subsystems within the framework of the sustainable development concept predetermined the transition to the socio-economic paradigm of financial reporting, designed to provide reliable information about the change in the value of capital in the context of the implementation of the sustainable development business model. Obviously that each of the subsystems (economic, social and environmental) has its own production factor - capital, which acts as a source of accumulation, and as a result of an increase in the business value. Hence the need for recognition, along with financial capital, and its new forms: human, social and natural capital.

According to the concept of ecological economics, the founders of which are recognized R.Costanza, H.Daly, the stock that is the source of a sustainable flow of natural (environmental) services and real natural resources is natural capital [26]. In this context, the Natural Capital Declaration adopted at the Rio+20 Summit (2012) recognized the relationship between natural and financial capital and, as a result, the need to reform the accounting and financial reporting system in order to disclose information on the natural capital value [8]. Nevertheless, non-financial reporting currently provides statistical information, the purpose of which is to confirm the compliance of doing business with environmental legislation.

However, the lack of data on natural capital in monetary terms contradicts the concept of capital, which is inseparable from the concept of economic calculation, and does not correspond from the point of Mises's view to the sociality of the capital structure [18], which ultimately can lead to the depreciation of the value of the business. Belaya M. emphasizes that despite the obviousness of the need to take into account natural capital and take into account the risks, uncertainties and opportunities associated with the use of natural capital services, not all business entities assess them and recognize them in their reporting [2]. The reasons for this problem include the next:

- $\quad$ lack of profound transformations in accounting theory [14];

- $\quad$ evolutionary processes in the theory of natural capital [22];

- the reporting structure, which is formed from the assumption that natural capital is eternal, and the orientation of managers to financial indicators of success [2].

To neutralize this problem, the United Nations Environment Programme (2016) consolidated the importance of natural capital, recognizing the feasibility of developing comprehensive balanced approaches to determining the value, accounting and calculating the contribution of natural capital to the sustainable development of society [23]. According to the international standard «Integrated reporting», it is clearly stated that since the activities of a business entity lead to the impact on capital that is the basis of its business model, it is necessary to define, describe and broadly consider all forms of capital that it owns or controls, including natural capital [17]. Assessment of socio-economic benefits generated by new forms of capital (human, social, natural) requires a new look at the structure of equity capital within a separate business entity. The types, size, quality, degree of development and directions of use of natural capital - all this has a direct impact on the economic potential of a business entity, therefore the socio-economic paradigm of financial reporting requires its recognition, and reliable assessment and distribution for the purpose of reproduction is an objective necessity. In this context, the problem of accounting for natural capital, along with other new value drivers, is key in modern accounting methodology.

\section{Literature review}

The study of the essence of capital is devoted to the works of famous representatives of various scientific schools: F.Quesnay, A.Turgot, D.Aleksander [1], L.Mises [18], T.Piketti [20], C.E. Sprague, I.Fisher, J.A. Schumpeter, E.S. Hendriksen, M.F. van Breda, J.R. Hicks, etc. The works of some of them, as well as a number of other scientists, economists and sociologists are aimed at studying the concept of capital of the XXI century and its new forms in the context of the development of society. These include works of I.Wallerstein [3], R.Kaplan, D.Norton [14], R.Costanza, H.Daly [26], C.McConnell, S.Brue [16], L.Mises [18], T.Piketti [20], etc. The application aspects regarding the recognition and assessment of natural capital are disclosed in the works of M.Belaya [2], D.A. Darbalaeva, T.G. Romanova, V.B. Yakovleva [7], M.Puhova [22], etc. The issue of accounting for certain types of natural capital through the prism of IFRS provisions, which is disclosed in detail in the article by V.Turcanu and I.Golochalova [25], also deserves attention. Methodological and theoretical support for the study is provided not only by various publications in scientific journals on the issue of accounting and valuation of natural capital, but also by official materials (Concept of ecological-economic accounting of natural capital, IFRS system, the legislative and regulatory framework of the Republic of Moldova), which made it possible to put forward hypotheses, formulate proposals and concrete conclusions. 


\section{The identification of previously unresolved issues and the formulation of research hypotheses}

Hypothesis 1: the current accounting system in the Republic of Moldova does not correspond to the socio-economic paradigm of financial reporting, in particular, the requirement to provide information on natural capital as a factor in the development of the environmental subsystem of a business entity and its impact on the growth of the equity capital of a business.

Hypothesis 2: natural capital accounting (natural resources and ecosystem services) as an element of the financial reporting of a business entity is based on the relationship between the concept of capital of the XXI century and modern accounting methodology (IFRS methodology), which adequately meets the socio-economic paradigm of financial reporting.

\section{Research methodology and methods}

The research was carried out on the basis of general scientific and special methods: a systematic approach, analysis, synthesis, modeling and abstraction, literature and document review, comparison and content analysis. The use of the fundamental general scientific method (dialectical research method) made it possible to consider such a phenomenon as natural capital accounting in the relationship and in the constant development of the classical theory of capital with new concepts: sustainable economy, environmental capital, fair value. The use of a systematic approach in research based on a combination of certain research methods is aimed at building a research methodology: formulating a research problem, proposing hypotheses and justifying them. While researching this topic, the authors were guided by special methods:

- analysis, with the help of which the distinctive features of natural capital and its similarities with other forms of capital are revealed;

- $\quad$ synthesis, which made it possible to formulate conclusions and substantiate the hypotheses put forward and substantiate the methodology of natural capital accounting;

- abstraction and modeling, on the basis of which a mechanism for recognizing natural capital as an element of financial reporting is proposed;

- finally, by the way of comparison and content analysis of the provisions of the legislative framework of the Republic of Moldova applied to natural capital, which made it possible to identify as contradictions between national strategic goals and institutional possibilities for their implementation.

The Republic of Moldova is currently facing a number of problems and long-term trends, one of which is ensuring the right to a healthy and safe environment, with significant consequences in the short term. As is well known, that the core of the institutional platform is the national development strategies and legislation, therefore, we briefly characterize each of them (Table 1). Following the requirement of European integration, expressed in the implementation of the Moldova-European Union Association Agreement (2014), the Government of the Republic of Moldova has developed the National Development Strategy «Moldova-2030» [19], which is based on the concept of sustainable development, used by EU countries. It might be pointed out that a detailed description of the National Development Strategy «Moldova-2030» is given in the work of I.Golochalova [27]. The national legal framework in force in the Republic of Moldova in relation to natural resources is represented by special legislative acts, in which, in order to fulfill the obligations under the Moldova-European Union Association Agreement, a number of amendments and additions have been made: Law of the Republic of Moldova of February 6, 1997, No. 1102-XIII «About natural resources» [10]; Law of the Republic of Moldova of May 29, 2014, No. 86 «About environmental impact assessment» [11], which is a partial transposition of Directive 2011/92/EC of the European Parliament and of the Council of 13 December 2011; Law of the Republic of Moldova of June 16, 1993, No. 1515-XII «About environmental protection» [9]; Law of the Republic of Moldova of December 15, 2017, No. 287 «About financial accounting and the financial reporting» [12].

Table 1

General characteristics of the components of the institutional platform for natural capital accounting

\begin{tabular}{|c|c|c|}
\hline $\begin{array}{c}\text { Official } \\
\text { document }\end{array}$ & $\begin{array}{c}\text { Characteristic } \\
\text { elements }\end{array}$ & Summary of characteristic element \\
\hline \multirow{3}{*}{ 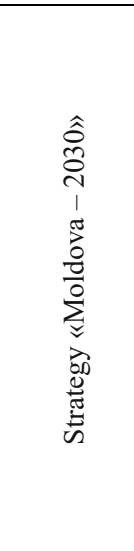 } & $\begin{array}{l}\text { Key area for } \\
\text { sustainable } \\
\text { development }\end{array}$ & $\begin{array}{l}\text { One of 10: ensuring access to quality natural capital and effective interaction with it. } \\
\text { The causes of this problem are: } \\
\text { - excessive attention to the phenomenon of economic growth to the detriment of economic development; } \\
\text { - the choice of business development as a priority direction, which led to the dehumanization of the } \\
\text { achievements of society as a whole }\end{array}$ \\
\hline & $\begin{array}{c}\text { Strategic vision of } \\
\text { a key area }\end{array}$ & $\begin{array}{l}\text { Integration of measures and principles of a green economy into the production processes of sectors of the } \\
\text { national economy aimed at using clean technologies and minimizing the risks of interacting with natural } \\
\text { capital in the economic sector, which will contribute to improving the quality of the environment and the } \\
\text { standard of living of the population }\end{array}$ \\
\hline & Priority actions & $\begin{array}{l}\text { Since existing mechanisms and national policies do not ensure the preservation and restoration of the main } \\
\text { components of the environment, develop: } \\
\text { 1) systems for monitoring and assessing the quality of environmental factors in accordance with international } \\
\text { requirements; } \\
\text { 2) an integrated system for managing the quality of ecosystem services (water, air, soil); } \\
\text { 3) a multifunctional system of accounting and management of the impact of the economic sector on natural } \\
\text { capital, contributing to the reduction of environmental risks }\end{array}$ \\
\hline
\end{tabular}


Continuation of the table 1

\begin{tabular}{|c|c|c|}
\hline $\begin{array}{c}\text { Official } \\
\text { document }\end{array}$ & $\begin{array}{c}\text { Characteristic } \\
\text { elements }\end{array}$ & Summary of characteristic element \\
\hline \multirow{5}{*}{ 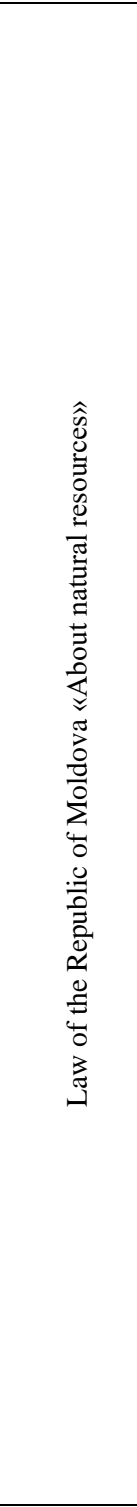 } & $\begin{array}{c}\text { General } \\
\text { provisions of } \\
\text { natural resources } \\
\text { concept (art. 1) }\end{array}$ & $\begin{array}{l}\text { - natural objects, the phenomena, conditions and other factors which were used in the past belong to natural } \\
\text { resources, are used in the present or will be used in the future for direct or indirect consumption, have } \\
\text { consumable cost and promote creation of material and spiritual riches; } \\
\text { - natural resources are used (or can be used) as labor instruments, power sources, raw materials and materials, } \\
\text { it is direct as consumer goods, in the recreational purposes as bank of genetic fund or source of information } \\
\text { on the world around }\end{array}$ \\
\hline & $\begin{array}{l}\text { Classification of } \\
\text { natural resources } \\
\quad(\text { art. } 3,5)\end{array}$ & $\begin{array}{l}\text { - renewable (natural resources which in the course of circulation of substances in the biosphere self-repair or } \\
\text { can be artificially filled for the period time, commensurable with terms of their consumption (with rate of } \\
\text { economic activity of the person)); } \\
\text { - not renewable (natural resources which in the course of circulation of substances in the biosphere do not } \\
\text { self-repair for the period time, commensurable with terms of their consumption (with rate of economic } \\
\text { activity of the person); } \\
\text { - operational (natural resources involved in economic operation (used)); } \\
\text { - reserve (natural resources, held for use, but not involved in economic operation (potentially suitable for use)); } \\
\text { - protected (natural resources which are of special value from the point of view of preserving ecological } \\
\text { equilibrium and cannot be involved in economic operation) }\end{array}$ \\
\hline & $\begin{array}{l}\text { Property right to } \\
\text { natural resources } \\
\text { and contractual } \\
\text { forms of their use } \\
\quad(\text { art. } 8,9,10)\end{array}$ & $\begin{array}{l}\text { - the property on natural resources can be public or private. The national natural resources which are in public } \\
\text { property belong to the state; } \\
\text { - the right of private property to natural resources is limited; } \\
\text { - the natural resources which are in public property are provided only in temporary ownership and use. } \\
\text { Natural resources can be provided in long-term use under lease or concessions if it does not contradict the } \\
\text { current legislation }\end{array}$ \\
\hline & $\begin{array}{l}\text { Establishing } \\
\text { principles for } \\
\text { natural resource } \\
\text { management } \\
\text { (art. 11). }\end{array}$ & $\begin{array}{l}\text { Including: } \\
\text { - ensuring their sustainable use; } \\
\text { - support of activities aimed at rational use of renewable and saving non-renewable natural resources; } \\
\text { - prevention of negative impact of economic activity on natural resources; } \\
\text { - use of natural resources for a fee, except for the cases of their restoration } \\
\end{array}$ \\
\hline & $\begin{array}{l}\text { Definition of the } \\
\text { mechanism of } \\
\text { payment for the } \\
\text { use of natural } \\
\text { resources } \\
\text { (art. } 14,15,19, \\
21-24 \text { ) }\end{array}$ & $\begin{array}{l}\text { Including: } \\
\text { - development and approval of standards and regulatory and technical requirements and types of activities in } \\
\text { the field of natural resources use; } \\
\text { - determination of objects of paid nature use, which include land, underground and surface waters, mineral } \\
\text { resources, forests, biological resources, wild animals and plants, air (for technological purposes); } \\
\text { - attributing the costs associated with their use to the cost of goods manufactured (services provided); } \\
\text { - development of an economic scheme for the management of natural resources, which is expressed in: } \\
\text { - planning and state financing of measures to identify, assess, preserve natural objects and restore damaged or } \\
\text { used natural resources; } \\
\text { - paid use of natural resources (payment for natural resources and for environmental pollution), which is the } \\
\text { main source of funds for public investment; } \\
\text { - setting the price for natural resources as a monetary compensation by the user of the public costs for their } \\
\text { exploration, preservation and restoration; } \\
\text { - carrying out a special investment policy in the use of natural resources based on estimates of the } \\
\text { «depreciation» of the natural resource potential; } \\
\text { - establishing adequate accounting for the costs of using natural resources and protecting the environment; } \\
\text { - stimulating activities to restore renewable natural resources }\end{array}$ \\
\hline
\end{tabular}

4
0
0

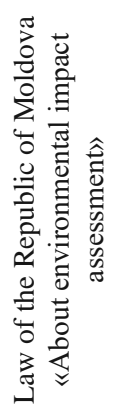

Purpose, subject of the law and basic concepts $($ art. 1,2)
On the natural resources of the economic zone, mineral wealth, water and forests, referring them exclusively to public property
The purpose of this law is creation of the legal basis of functioning of the mechanism of environmental impact assessment of some state and private projects or types of the planned activities for ensuring prevention or decrease in negative impact on the environment and health of the population at the earliest stages.

The subject of this law are the procedures and procedure used in the course of environmental impact assessment of some state and private projects or types of the planned activities which can make considerable impact on the environment of the Republic of Moldova or other states.

Basic concepts: environmental impact assessment - the procedure performed according to this law for the purpose of assessment of possible impact on the environment of the planned activities and also for development of offers on prevention and decrease in negative impact or, in case of violation of the requirements provided by this law, - for prohibition of the beginning of realization of the planned activities; impact the environment - the direct or indirect changes of the environment caused by realization of the planned activities which influence or can influence both health of the person, and biodiversity, the soil, subsoil, water, air, climate, landscape, material values, cultural heritage, and also interrelation between the listed factors 


\begin{tabular}{|c|c|c|}
\hline $\begin{array}{c}\text { Official } \\
\text { document }\end{array}$ & $\begin{array}{c}\text { Characteristic } \\
\text { elements }\end{array}$ & Summary of characteristic element \\
\hline \multirow{2}{*}{ 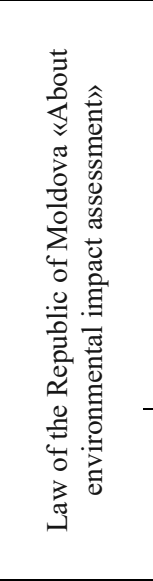 } & $\begin{array}{l}\text { Forms for } \\
\text { assessing the } \\
\text { impact on the } \\
\text { environment and } \\
\text { the scope of its } \\
\text { application } \\
\quad \text { (art. } 3,4)\end{array}$ & $\begin{array}{l}\text { The following principles: } \\
\text { - principle of preventive actions; } \\
\text { - principle of reliability and completeness of information; } \\
\text { - principle of transparency and availability; } \\
\text { - principle of participation; } \\
\text { - principle of precaution; } \\
\text { - the principle «pays pollutant». } \\
\text { Scope of environmental impact assessment: } \\
\text { - population, fauna and flora; } \\
\text { - soil, subsoil, water, air, climate and landscape; } \\
\text { - material values and cultural heritage; } \\
\text { - interrelation between the identified factors, long-term and cumulative }\end{array}$ \\
\hline & $\begin{array}{l}\text { Determination of } \\
\text { the environmental } \\
\text { impact } \\
\text { assessment } \\
\text { mechanism }\end{array}$ & $\begin{array}{l}\text { Including: } \\
\text { - preliminary assessment of the planned activity (Chapter III, art. 9-10); } \\
\text { - assessment in a transboundary context for the party of origin (Chapter IV, art. 11-15); } \\
\text { - assessment in a transboundary context for the affected party (Chapter V, art. 16-18); } \\
\text { - assessment at the national level (Chapter VI, art. 19-24) }\end{array}$ \\
\hline \multirow{3}{*}{ 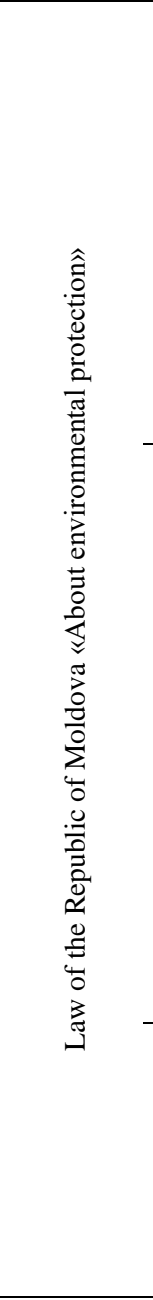 } & $\begin{array}{l}\text { Definition of } 6 \\
\text { basic purposes } \\
\text { (art. 2) }\end{array}$ & $\begin{array}{l}\text { Including: } \\
\text { - providing to each person of the right to healthy and esthetically pleasant circle; } \\
\text { - instilling in each generation of people of feeling of the highest responsibility for protection of the circle to } \\
\text { the subsequent generations; } \\
\text { - achievements of the broadest range of use of natural resources without exceeding of admissible limits, } \\
\text { preventing their depletion and degradation, health hazard of people and other undesirable and unpredictable } \\
\text { effects; } \\
\text { - protection of the earth and subsoil, water and air from chemical, physical and biological pollution, from } \\
\text { other impacts breaking economic equilibrium; } \\
\text { - preserving biological diversity and gene pool, integrity of natural systems, national historical and cultural } \\
\text { values; } \\
\text { - recoveries of the ecosystems and their components broken as a result of anthropogenous activities or natural } \\
\text { disasters }\end{array}$ \\
\hline & $\begin{array}{l}\text { Formation of } 8 \\
\text { principles of } \\
\text { environmental } \\
\text { protection (art. 3) }\end{array}$ & $\begin{array}{l}\text { Including: } \\
\text { - priority is more whole also than activities for protection of environment in case of realization of economic } \\
\text { and public and humanistic interests of the population in the present and the future; } \\
\text { - obligation of execution of the legislation on protection of the circle, observance of standards, standard rates and } \\
\text { admissible limits of use of natural resources and energies, impacts of chemical, physical and biological factors on } \\
\text { components of the circle, harmful emissions, dumpings and accumulating of waste from economic activity; } \\
\text { - paid use of the earth, subsoil, waters, the woods in the economic and public and humanistic purposes } \\
\text { according to the current legislation; collection of duties and imposing of penalties for violation of the law } \\
\text { about protection of the circle; the direction of the means received thus only on pollution abatement of the } \\
\text { circle, depletion of natural resources and development of dangerous geological processes, and also on } \\
\text { improvement of the circle and its components and reproduction of natural resources; } \\
\text { - stimulation of implementation of resource-saving technologies by means of provision of soft credits and } \\
\text { different ways, increase in responsibility of users of nature by delivery of natural resources by it in long-term } \\
\text { lease; } \\
\text { - understanding by the population of need of establishment of the fruitful and harmonious relations between } \\
\text { the person and the circle surrounding it and taking measures to prevention of threat for the biosphere and } \\
\text { health of the person }\end{array}$ \\
\hline & Defines & $\begin{array}{l}\text { - powers and competences of environmental administration: } \\
\text { - Parliament, President of the republic, Government, Local Authorities (Chapter II, art. 6-10) } \\
\text { - Department of the Environment (Chapter III, art. 11-25) } \\
\text { - Inspectorate for Environmental Protection (Chapter III, art. 26-29) } \\
\text { - Environmental Agencies (Chapter III, art. 29) } \\
\text { - rights and obligations of legal entities and individuals in the field of environmental protection (Chapter IV, } \\
\text { art. 30-32) } \\
\text { - measures for environmental protection (Chapter V, art. 33-94) }\end{array}$ \\
\hline 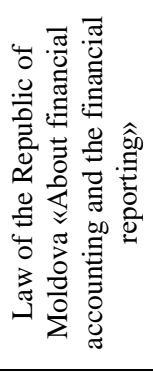 & $\begin{array}{l}\text { Management } \\
\text { report (art. 23) }\end{array}$ & $\begin{array}{l}\text { A management report that includes the following information: } \\
\text { - financial performance indicators; } \\
\text { - non-financial performance indicators that are significant for the entity's activities; } \\
\text { - prospects for the development of the entity; } \\
\text { - environmental protection and professional capabilities of employees. } \\
\text { Non-financial declarations (for entities of public interest that meet the criteria established for large entities } \\
\text { and with an average headcount in the reporting period of more than } 500 \text { employees), which contains } \\
\text { information on social and environmental issues, etc. and includes: } \\
\text { a) a brief description of the entity's business model; } \\
\text { b) a description of the policies and procedures applied and the results obtained by the entity; } \\
\text { c) the main risks and the order in which they are managed }\end{array}$ \\
\hline
\end{tabular}

Source: developed by the authors based on $[6,9-12,19]$ 
A number of other laws are in force in the Republic of Moldova has a number of other laws are in force (Law of the Republic of Moldova of December 17, 1997, No. 1422-XIII «About protection of atmospheric air», Law of the Republic of Moldova of February 25, 1998, No. 1540-XIII «About payment for environmental pollution», etc.), however, within the framework of this study, attention is focused on the basic legislative acts.

The National Development Strategy «Moldova-2030» provides an assessment of the current state of natural capital, according to which there are phenomena in the Republic of Moldova that indicate its degradation, namely: limited access to quality water sources; air and soil pollution; noise pollution; the use of outdated energy approaches; the loss of the productive potential of water and land resources under the influence of agricultural reforms and the transition to new forms of ownership [19]. If the current trends continue, then in the republic:

- $\quad$ natural capital will become more expensive, and the costs associated with its use will be borne not only by enterprises in the extractive industries, but also by the manufacturing industry, transport, and the service sector;

- loss of natural capital will affect consumer preferences, owner expectations, tax regimes, government policies, employee welfare, and availability of finance and insurance.

The economic realities of the Republic of Moldova, operating in the context of the COVID-19 pandemic, are confirmation of the above: the drop in GDP in 2020 compared to 2019 was 7,2 \%, production decreased - industrial by $6,9 \%$, and agricultural - by 2,8\%; the financial losses of the air transport sector amounted to 10,1 million euros in 9 months of 2020 , the state-owned enterprise «Railroad» whose debts reached 21,67 million euros, was declared bankrupt, and the losses in the tourism sector are such that it is on the verge of extinction as an economic sector. The strategy emphasizes that in order to neutralize the uncertainties and unpredictability of the environmental impact on society, it is necessary to apply new development paradigms, taking into account the national potential of natural resources.

\section{Main results}

Conceptual rationale for the recognition of natural capital. Analysis of the provisions of the legislative framework of the Republic of Moldova (Table 1) allows us to draw a conclusion about the continuing trend of supporting the economic growth of the business environment within the framework of state management of natural resources, which is primarily manifested in the establishment of principles and a certain mechanism of payment for the use of natural resources (Law No. 1102- XIII [10]). The implementation of the concept of sustainable development will be complicated by the existing contradictions in the legislative framework of the Republic of Moldova, for example:

- between the principles (reliability and completeness, transparency and accessibility) for environmental impact assessment (Law No. 86 [11]) and the requirements for disclosure of information on the impact of business on the environment established by Law No. 287 [12] on accounting and financial reporting, the format of which is statistical in nature;

- between the requirement to establish adequate accounting for the costs of the use of natural resources and environmental protection (Law No. 1102-XIII [10]) and the principle of the legal approach to preparing financial statements «prescription and clarity», which is enshrined in Law No. 287 [12, art. 6]. This circumstance excludes the presentation of useful information necessary for making economic decisions by a wide range of users and casts doubt on the adequacy of accounting for transactions related to natural resources.

The problem of the inconsistency of Law No. 287 [12] and the regulatory framework of the Republic of Moldova in the field of accounting and their adequacy to the requirements of the socio-economic paradigm of financial reporting is revealed in works $[27,28]$.

The above substantiates Hypothesis 1: the accounting system of the Republic of Moldova does not correspond to the socioeconomic paradigm of financial reporting on the presentation of balanced information on the impact of the environmental subsystem on the growth of the value of a business entity, as well as on the participation of business in the implementation of a sustainable development model.

We support Wallerstein's point of view, according to which the problem of natural capital should be viewed through the prism of capitalist civilization and the functioning of a business entity in it [3]. It is a well-known fact that capital growth has certain limits, and in the conditions of an economic crisis, these opportunities are further reduced. The state, realizing the need to maintain a business as a taxpayer and a job creator, pursues a policy of regulating the activities of a business entity, usually in two ways:

- the conclusion of agreements either on subsidies, but which today are considered as a political instrument, or agreements of public-private partnership;

- covering part of the costs of a business entity by excluding production costs from the cost of production and, first of all, the costs of ecosystem services [3].

Obviously that the second way (hiding environmental costs) is the simplest and most effective way to increase capital, but this way leads to the dehumanization of the achievements of society and excludes its sustainable development since other business entities are forced to spend additional funds to restore natural capital. In this context, in order to level this phenomenon in the National Development Strategy «Moldova-2030», the development and implementation of a new mechanism of interaction between business and natural components are designated as a priority direction of the national policy (Table 1).

It is advisable to emphasize that the promotion of the concept of natural capital in the Republic of Moldova should be scientifically substantiated, and its accounting should be based on modern accounting methodology (IFRS methodology), 
which accumulates the concept of capital of the XXI century and fair value, and the purpose of which is to provide useful information to a wider circle of users. To achieve the goal of financial reporting, which is to provide useful information for making management decisions, the compiling organizations should provide not only information about economic resources, but also about the factors that caused their changes, one of which is capital. However, in the context of the transition to the socio-economic paradigm of financial reporting, when there is a need for balanced information on the value and changes of each type of capital, including its new forms, this is a rather difficult task that requires a conceptual justification.

The classical interpretation of capital in the XXI century has not undergone significant changes and consists in its understanding as a set of goods and property of the owner, which allow you to receive additional income (capital income and labor income), distributed between the owners: capital (profit, dividends, interest) and employed employees (remuneration, fees, salary). At the same time, as L.Mises emphasizes, the theory of capital, focusing on the needs of the business environment, was adapted to the concept of financial capital, in favor of constructed real capital [18], and neglected land and natural resources, recognized by the theory of physiocrats as a source increments of wealth. So, even F.Quesnay (1897) noted the need to take into account free natural goods and separate those goods that have consumer value, but do not have a selling price from those that have both values. A.Smith (1987) recognized the special importance of human resources and natural wealth, which have value in the same way as the product of employed workers [4].

We support Mises's point of view, according to which the fact that even today there is no information on the change in the monetary equivalent of land in the financial statements, despite the presentation of the total value of the land in it [18]. This means that the financial statements do not show how the activity of the business entity affected the ability of the land to participate in the production process: whether this ability or activity has been preserved has led to a decrease in the objective use value of the land, and, as a consequence, to a decrease in the cost of capital in general.

Another well-known economist T.Piketti also adheres to the generally accepted interpretation of capital, as expressed in market prices of the total value of non-financial and financial assets, from which financial liabilities (debts) are subtracted, and which at a specific point in time can be exchanged on the market [20]. T.Piketti distinguishes the following types of it: financial and professional, used by management personnel, and fixed capital used by the enterprise. Natural resources, being part of the total economic resources, are formed under the influence of a separate factor of production - natural capital, but for its recognition it is necessary, first of all, to solve the problem of assessment. Namely, to clearly divide the total value of a land plot into the value of land donated to humanity and the value of agricultural improvements. Also from the total cost of natural resources to highlight the effect of investment, thanks to which it became possible to discover the deposit and its operation [20]. The developers of the theory of natural capital (ecological theory of capital) R.Costanza and H.Daly, taking the classical interpretation of capital as a basis, understand natural capital as a stock that ensures the flow of valuable goods and eco-services in the future, while it not only lies in the basis of all other forms of capital, but is also able to oust them from economic circulation [26]. A feature of this definition is the fact that natural capital is treated as separate components of nature and the relationship between them (eco-services).

If natural resources are steadily identified with natural capital, then in relation to ecosystem services, it is necessary to establish coinciding characteristics for their identification as a form of natural capital. In this context, their interpretation given by L.Mises deserves attention: eco-services, participating in the production process, are both physically and economically integrated in it, and, although physically they subsequently disappear, but economically remain - they are first replaced by intermediate products, and then the product, which is the end result [18]. This process is continuous and repeatable. According to the report of the conceptual working group on the Millennium Ecosystem Assessment, ecosystem services, which are categorized by functional value and organizational purpose, are understood to be the benefits that people receive from ecosystems [29]. The foregoing is the rationale for the following conclusion: eco-services are cumulative natural capital, moreover, restored, in the absence of which the process of capital accumulation would have to start anew, and this would require additional time, which would significantly slow down the growth of capital by the business.

Gylfason T. also adheres to the interpretation of natural capital as a set of natural resources and ecosystem services, revealing in his study the process of its influence on the development of a separate economic system, however, unlike L.Mises and the founders of the theory of natural capital, he is critical to their point of view on the dominant role of natural capital in the increment of wealth, giving priority in this process to human capital [5]. The approach of modification of one form of capital is conceptualized and embodied in the Integrated Reporting standard, the basic idea of which is the dynamic transformation of the amount of capital: one type of capital is transformed into another as a result of constant circulation.

Natural capital also has other properties of capital, namely, when used, it depreciates, which creates material and financial risks for business structures both in the short and long term. We support Belaya's point of view, according to which that those organizations that take into account the risks associated with the use of natural capital earlier than others and take advantage of the opportunities that have opened up for innovation and risk management will succeed [2]. The well-known economists K.McConnell and S.Brue also adhere to this point of view. They note that the transformation of a part of external costs associated with the use of natural resources into internal costs of the development of innovative technologies for the efficient use of the environment is aimed at maintaining the size natural capital [16]. The theoretical basis for leveling the effect of loss of capital value over time is the concept of J.Hicks (2005) - maintaining the amount of capital, on the application of which modern accounting methodology (IFRS methodology) and its concept of preparing financial statements are based [1].

Based on the analysis of existing interpretations, it seems logical to conclude that natural capital has a number of economic characteristics inherent in other forms of capital: it is converted into financial capital, yields dividends in the future, changes its value over time, requires investment support, and affects the total value of a business entity. 
These studies have made a significant contribution to the evolution of the theory of natural capital and found their embodiment in the concept of sustainable development, adopted for implementation by the countries of the European space. So, in the National Development Strategy «Moldova-2030» to ensure access to high-quality natural capital, a strategic approach to integrate measures and principles of a green economy into the production processes of sectors of the national economy, aimed at using clean technologies and minimizing the risks of interacting with natural capital in the economic sector (Table 1).

Methodological aspects of accounting natural capital. To understand the role of accounting in the process of presenting information on capital, it is enough to cite the opinion on this issue of the well-known economist L.Mises: the procedure for accumulating capital, or its «eating up» as a result of excessive consumption, is controlled by accounting - the pinnacle of economic calculation, with which provides an opportunity to reveal the differences between economic property and the benefits derived from it [18]. Based on the accounting methodology, the essence of capital should be viewed through the prism of its interpretation: as an element of financial reporting and as a set of accounting objects that have a certain economic content. According to the modern accounting methodology, in order to recognize one or another object of observation as an element of financial reporting, it is necessary to identify an event (phenomenon, fact) as economically useful, the implementation of which leads to the emergence of accounting objects. We support Puhova's point of view, according to which the fact that, in essence, natural capital is, first of all, a natural phenomenon and for its recognition as an «economic phenomenon» (economic object), a detailed study of the nature of this transformation as a result of the use of financial and human capital is needed [22].

The interpretation of capital as an element of financial reporting is well known - it is the residual value of the assets of an economic entity after deducting all of its liabilities from their value. From a legal point of view, capital provides for the extension of the rights of owners to its certain share in the property of a legal entity. In this part, the authors support the point of view of D.A. Darbalaeva that it is necessary to establish the following criteria for recognizing natural capital as an element of financial statements:

- $\quad$ for the economic assets of the institutional unit, the property right must be enforced;

- owners of economic assets receive economic benefits from the use, ownership, disposal [7].

However, the right to natural resources in most countries, including the Republic of Moldova, belongs to the state. In the context of the above, the expediency of a separate presentation of information in the reporting on natural capital, the contribution of which belongs to the state, and in fact to the society as a whole, from the capital formed from the contributions of owners (investors and shareholders), is obvious.

So, from the standpoint of modern accounting methodology focused on the socio-economic paradigm of financial reporting, natural capital should be reflected in financial statements: on the one hand, in the «Assets» section, on the other, in the «Liabilities» section, but as what is its element, capital or obligation?

Often, business entities carry out their activities thanks to state support in the form of subventions or subsidies, when their property is used on a mixed basis: one part is by ownership, and the other, which is the result of subsidies, is based on the controllability principle. As noted by T.Piketty, in this case we are talking about a rather original form of ownership, which is an intermediate link between exclusively private property and state property - funds with a specific purpose and which belong to legal entities [20]. It is pertinent to emphasize that the IFRS methodology allows, on the basis of professional judgment, to adequately solve the problem of recognizing and reporting natural capital: the provisions of IAS 20 «Accounting for Government Grants and Disclosure of Government Assistance», providing an alternative «capital» method for displaying subsidies, are applicable natural resources. In this context, according to the authors, it is quite appropriate to use a separate account in the «Capital» - «Natural Capital Funds» section. The author's position in relation to accounting for natural capital is presented in Table 2 .

Table 2

Proposed model for recognizing two types of natural capital

\begin{tabular}{|c|c|c|c|c|}
\hline \multirow{2}{*}{ Types } & \multirow{2}{*}{$\begin{array}{l}\text { Description of } \\
\text { transaction }\end{array}$} & \multicolumn{2}{|c|}{ Account title } & \multirow{2}{*}{ Calculation of the amount } \\
\hline & & Debit & Credit & \\
\hline \multirow{4}{*}{$\begin{array}{l}\text { Natural } \\
\text { resources }\end{array}$} & Initial & Natural reserves & Deferred income & Fair value of inventory \\
\hline & $\begin{array}{l}\text { recognition of } \\
\text { natural resources }\end{array}$ & Natural reserves & Target financing & $\begin{array}{l}\text { The size of the contribution of the environment to } \\
\text { the value of the business }\end{array}$ \\
\hline & $\begin{array}{c}\text { Recognition of } \\
\text { natural capital }\end{array}$ & Target financing & Natural capital funds & $\begin{array}{l}\text { The size of the contribution of the environment to } \\
\text { the value of the business }\end{array}$ \\
\hline & $\begin{array}{l}\text { Recognizing } \\
\text { environmental } \\
\text { costs }\end{array}$ & Deferred costs & Provisions & $\begin{array}{c}\text { Capitalized value of liabilities to restore the } \\
\text { environment }\end{array}$ \\
\hline $\begin{array}{l}\text { Ecosystem } \\
\text { services }\end{array}$ & $\begin{array}{l}\text { Recognition of } \\
\text { natural capital }\end{array}$ & Retained earnings & $\begin{array}{l}\text { Ecosystem support } \\
\text { funds }\end{array}$ & $\begin{array}{l}\text { Assessment of risks and uncertainties of } \\
\text { ecosystem quality }\end{array}$ \\
\hline
\end{tabular}

It is important to note that the recognition of deferred expenses arising from the need to restore the environment, regulated by the provisions of IAS 37 «Provisions, Contingent Liabilities and Contingent Assets» and IFRIC «Changes in existing obligations for the dismantling and decommissioning of property, plant and equipment, environmental remediation and similar liabilities» does not lead to the formation of natural capital. 
The next problematic aspect of the recognition of natural capital and its reflection in financial statements is the lack of an effective methodology for assessing the risks associated with the devaluation of the ecosystem due to the provision of ecosystem services to the business environment. Currently, in world practice, there are two main approaches to assessing natural resources: the cost method, which is based on the cost of developing natural resources; the income method, based on calculating the efficiency of use, during the duration of the investment project. It is pertinent to emphasize that within the framework of the income approach, there are several economic concepts for assessing natural resources, called indirect methods: opportunity cost (lost profit), total economic value (cost), full economic value. However, in the context of this study, the assessment issue is disclosed from the standpoint of accounting methodology.

It should be noted that, within the framework of the US GAAP system, SFAS No. 69 «Disclosures about Oil and Gas Producing Activities» was developed, which provides for the application of a standardized assessment of discounted future net cash flows for the assessment of proved natural resources. The difference between this method and the traditional discounting method is that the discounting of future net flows is carried out using a $10 \%$ discount rate [21]. Using this method (which refers to the income-based approach to estimating natural resources) provides a more accurate estimate than estimates based on cumulative costs alone and is consistent with long-term trends in mineral prices. The IASB concluded that the standardized estimate is far from perfect, but this information is nonetheless referred to in the absence of other sources. And it serves not so much to represent the value of inventory, but to provide external users with information (investors and lender) that they can use to assess the attractiveness of the organization and its market prospects.

Note that there are standards in the IFRS system, the provisions of which directly indicate the feasibility of assessing natural resources: IAS 2 «Inventories» - mineral reserves in accordance with the method of standardized estimation of discounted future net cash flows; IAS 41 «Agriculture» - biological assets at fair value. The effectiveness of the application of standardized value in accounting for natural resources is disclosed in the work of V.Turcanu and I.Golochalova [25]. In this regard, it should be recalled that the accounting system of the Republic of Moldova is oriented towards the continental (European) model, according to which financial statements are prepared on the basis of a legal approach, which gives an accurate picture of the financial situation of the organization that is reporting. Therefore, as a consequence, the application of the concept of fair value assessment (trends in the Anglo-Saxon accounting and reporting model) in the national accounting system of the Republic of Moldova is not yet envisaged, and this indicates the absence of a conceptual space for presenting information on natural capital as a result of the participation of the business environment in ensuring sustainable development of society.

The above stated Hypothesis 2 is substantiated: the IFRS methodology in conjunction with the economic theory of capital of the XXI century allows solving the problem of accounting for natural capital in the context of the transition to the socioeconomic paradigm of financial reporting.

However, the assessment of the costs of ecosystem services remains unresolved. The analysis of these costs is important when developing a business entity's strategy, determining the impact of natural capital on the growth in the value of a business as a whole, calculating the contribution of a business entity to ensuring the sustainability of a region's development. The importance of recognizing, evaluating and accounting for natural capital is so great that by now the Central Framework of the System of Environmental-Economic Accounting (SEEA) has been developed, which is a multipurpose conceptual framework that describes the interaction between the economy and the environment [24]. Within the framework of the SEEA, methods for measuring ecosystem services are provided, the selection and adaptation of which in practice should be approached from a position of pragmatism and solve the problem of reliable presentation of information about the natural capital in general in the reporting of a business entity. The disclosure of this problem should be aimed at future research.

\section{Concluding remarks}

Natural capital has a number of economic characteristics that allow it to be recognized as an element of financial statements, subject to the relevant recognition criteria. In the context of the transition to the socio-economic paradigm of financial reporting based on the IFRS system, types of natural capital should be identified and separately recognized. In the section «Capital» in accordance with IAS 20, the costs of dismantling equipment and restoring the natural landscape do not directly lead to the recognition of natural capital due to non-compliance with the recognition criteria. The Republic of Moldova accounting system lacks a conceptual space for obtaining reliable information on the value of natural capital and its contribution to the total value of a business entity. The authors proposed a model for recognizing natural capital, depending on its types, corresponding to the socio-economic paradigm of financial reporting. To implement the requirement to present reliable information in financial statements on natural capital, it is necessary to unify the methodology for its assessment, the problem of which is currently debatable.

\section{References:}

1. Aleksander, D., Britton, A. and Iorissen, E. (2005), Mezhdunarodnye standarty finansovoi otchetnosti: ot teorii $k$ praktike, Translated from English, Vershina, M.

2. Belaya, M. (2016), «Prirodnyi kapital v sovremennoi ekonomike», Vestnik REU im. G.Plekhanova, No. 2 (86), pp. 59-68, [Online], available at: https://cyberleninka.ru/article/n/prirodnyy-kapital-v-sovremennoy-ekonomike/viewer

3. Vallerstain, I. (2004), Konets znakomogo mira: Sotsiologiya XXI, Translated from English, Logos, M.

4. Cherkovets, V. (ed.) (1987), Vsemirnaya istoriya ekonomicheskoi mysli, in 6 vol., Vol. 1, MGU im. M.V. Lomonosova, Mysl', M.

5. Gilfason, T. (2008), «Mirovaya ekonomika prirodnykh resursov i ekonomicheskii rost», Ekonomicheskii zhurnal VShE, No. 2, pp. 201-215, [Online], available at: https://gos.hse.ru/e-resources/HSE_economic_journal/articles/12_02_04.pdf 
6. Parlament Respubliki Moldova (2002), Grazhdanskii Kodeks Respubliki Moldova, Kodeks No. 1107 ot 06.06.2002, s izmeneniyami na 09.07.2020, [Online], available at: https://www.legis.md/cautare/getResults?doc_id=110277\&lang=ru

7. Darbalaeva, D., Romanova, T. and Yakovleva, V. (2012), Prirodnyi kapital v ustoichivom razvitii ekologo-ekonomicheskoi sistemy, Izd-vo SPbGUEF, SPb.

8. Ot perekhodnogo perioda $k$ transformatsii: ustoichivoe $i$ vseob"emlyushchee razvitie v Evrope $i$ Tsentral'noi Azii, Doklad OON, [Online], available at: https://unece.org/fileadmin/DAM/publications/oes/ECE_RIO_20_RUS.pdf

9. Parlament Respubliki Moldova (1993), Ob okhrane okruzhayushchei sredy, Zakon No. 1515-XII ot 16.06.1993, s izmeneniyami na 08.11.2018, [Online], available at: https://www.legis.md/cautare/getResults?doc_id=111735\&lang=ru

10. Parlament Respubliki Moldova (1997), O prirodnykh resursakh, Zakon No. 1102-XIII ot 06.02.1997, s izmeneniyami na 27.10.2017, [Online], available at: https://www.legis.md/cautare/getResults?doc_id=109389\&lang=ru

11. Parlament Respubliki Moldova (2014), Ob otsenke vozdeistviya na okruzhayushchuyu sredu, Zakon No. 86 ot 29.05 .2014 , s izmeneniyami na 21.09.2017, [Online], available at: http://extwprlegs1.fao.org/docs/pdf/mol137960.pdf

12. Parlament Respubliki Moldova (2017), O bukhgalterskom uchete i finansovoi otchetnosti, Zakon No. 287 ot 15.12.2017, s izmeneniyami na 16.12.2020, [Online], available at: http://lex.justice.md/index.php?action=view\&view=doc\&lang=2\&id=373601

13. Kaz, E., Krakovetskaya, I., Nekhoda, E. and Redchikova, N. (2020), Biznes-modeli kompanii $i$ ustoichivoe razvitie, Izdatel'stvo Tomskogo gosudarstvennogo universiteta, Tomsk.

14. Kaplan, R. and Norton, D. (2003), Sbalansirovannaya sistema pokazatelei: ot strategii k deistviyu, ZAO «Olimp - Biznes», M.

15. «Kontseptsiya ustoichivogo razvitiya», [Online], available at: https://csrjournal.com

16. Makkonell, K. and Bryu, S. (1992), Ekonomiks: Printsipy, problemy i politika, in 2 vol., 11th ed., Translated from English, Vol. 1, Respublika, M.

17. Mezhdunarodnyi standart «Integrirovannaya Otchetnost'», [Online], available at: https://integratedreporting.org/wpcontent/uploads/2015/03/13-12-08-THE-INTERNATIONAL-IR-FRAMEWORK.docx_en-US_ru-RU.pdf

18. Mizes, L. (2012), Chelovecheskaya deyatel'nost'. Traktat po ekonomicheskoi teorii, 3nd ed., Translated from English, Sotsium, Chelyabinsk.

19. Natsional'naya strategiya razvitiya «Moldova-2030», [Online], available at: http://www.mei.gov.md

20. Piketti, T. (2016), Kapital v XXI veke, Ad Marginem Press, Moskva.

21. Primenenie MSFO (Ernst\&Young) (2008), in 5 part, 3nd ed., pererab. i dop., Translated from English, Al'pina Biznes Buks, M.

22. Pukhova, M. (2008), «Prirodnyi kapital kak chast' sostavlyayushchego prirodnykh resursov», Sovremennye problemy nauki $i$ obrazovaniya, No. 2, pp. 130-132, [Online], available at: http://www.science-education.ru/ru/article/view?id=2669

23. «Ustoichivoe regulirovanie prirodnogo kapitala v tselyakh ustoichivogo razvitiya i iskoreneniya nishchety», Assambleya OON po okruzhayushchei srede Programmy OON po okruzhayushchei srede, [Online], available at: https://wedocs.unep.org

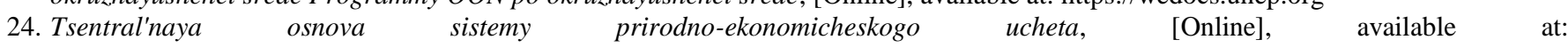
https://unstats.un.org/unsd/envaccounting/seeaRev/CF_trans/SEEA_CF_Final_ru.pdf

25. Tsurkanu, V. and Golochalova, I. (2015), «Nekotorye aspekty bukhgalterskogo ucheta mineral'nykh resursov v kontekste MSFO», Nauchnyi Vestnik Uzhgorodskogo universiteta, sbornik nauchnykh rabot, Seriya Ekonomika, Issue 1 (45), pp. 53-59, [Online], available at: http://www.visnyk-ekon.uzhnu.edu.ua/index.php/uk/

26. Costanza, R. and Daly, H. (1992), «Natural Capital and Sustainable Development», Conservation Biology, No. 6, pp. 37-46.

27. Golochalova, I. (2020), «Pension provision recognition and assessment as a type of social capital in the context of the financial reporting socio-economic paradigm: international practice and national experience», Public Policy and Accounting, No. 1, doi: https://doi.org/10.26642/ppa-2020-1-18-29.

28. Golochalova, I. (2019), «Analysis of the Statement of Stockholders' Equity in the Context of an Institutional Platform for Small Business Sector of the Republic of Moldova», Journal of Finance and Accounting, Vol. 7, No. 5, pp. 136-145, [Online], available at: http://www.sciencepublishinggroup.com/journal/paperinfo?journalid=171\&doi=10.11648/j.jfa.20190705.12

29. Millennium Ecosystem Assessment, [Online], available at: https://millenniumassessment.org

30. Report of the United Nations Conference on Environment and Development (1993), Rio de Janeiro, 3-14 June 1992, [Online], available at: https://undocs.org/en/A/CONF.151/26/Rev.1(vol.I)

\footnotetext{
*** How to cite this article: Golochalova I., Vakun O. Natural capital accounting in the context of the socio-economic paradigm of financial reporting: conceptual and methodological aspects. Public Policy and Accounting. 2020, Vol. 2 (2). https://doi.org/10.26642/ppa-2020-2(2)-24-33.
} 